\title{
Cara pengolahan limbah cair brown crepe untuk menurunkan bahan pencemar
}

\author{
Some ways of processing rubber brown crepe liquid waste to \\ reduce pollutants
}

\author{
Sri Sutyasmi*, Ike Setyorini, Prayitno \\ Balai Besar Kulit, Karet dan Plastik, Jl. Sokonandi No.9, Yogyakarta 55166, Indonesia \\ *Penulis Korespondensi. Telp. +62 274 512929, 563939; Faks. +62 274563655 \\ E-mail: srisutyasmi@ymail.com
}

Diterima: 16 Mei 2018

Direvisi: 15 Oktober 2018

Disetujui: 20 Oktober 2018

\begin{abstract}
The purpose of this research was to treat the liquid waste of brown crepe in order to decrease pollutant load. The liquid waste of brown crepe is processed using 3 models of processing. The models were primary processing and adsorption, processing from the container tub directly to the sand filter, and the primary processing continued to the sand filter. The results showed that coconut shell charcoal adsorbent can reduce the load for experiment 1: COD 75.91\%, BOD 73.94\%, TSS 95.07\% and N-Ammonia 91.23\%. Experiment 2: COD 91\%, BOD 95\%, TSS 84\% and N-Ammonia 61\%. Experiment 3: COD 65\%, BOD 65\%, TSS 88\% and N-Ammonia $81 \%$. All three trials can reduce pollutant load, but the most effective is experiment no 2 because it can decrease the highest COD and BOD pollutant load. Flowrate used in experiment 2 do not affect the decrease in pollutant load.
\end{abstract}

Keywords: Adsorbent, brown crepe, sand filter, waste water treatment

\begin{abstract}
ABSTRAK
Tujuan dari penelitian ini adalah untuk mengolah limbah cair brown crepe agar bisa menurunkan beban pencemar. Limbah cair brown crepe diolah dengan menggunakan 3 model pengolahan yaitu dengan pengolahan primer dan adsorpsi, pengolahan dari bak penampung langsung ke sand filter, dan pengolahan primer yang dilanjutkan ke sand filter. Hasil uji laboratorium menunjukkan bahwa penggunaan adsorben arang tempurung kelapa dapat menurunkan beban pencemaar untuk percobaan 1: COD 75,91\%, BOD 73,94\%, TSS 95,07\% dan NAmonia 91,23\%. Percobaan 2: COD 91\%, BOD 95\%, TSS 84\%, dan N-Amonia 61\%. Percobaan 3: COD 65\%, BOD $65 \%$, TSS $88 \%$ dan N-Amonia $81 \%$. Dari ketiga percobaan semua dapat menurunkan beban pencemar, namun yang paling efektif adalah percobaan 2 karena bisa menurunkan beban pencemar COD dan BOD paling tinggi. Variasi debit yang digunakan pada percobaan 2 tidak mempengaruhi penurunan beban pencemar.
\end{abstract}

Kata kunci: Adsorben, brown crepe, pengolahan limbah cair, sand filter

\section{PENDAHULUAN}

Indonesia adalah penghasil karet alam terbesar nomor 2 di dunia pada tahun 2010 yaitu sekitar 28\%, sedangkan Thailand adalah penghasil karet dunia nomor 1 yaitu sekitar $30 \%$. Pengusaha kecil karet di Indonesia adalah yang terbanyak menghasilkan karet alam yaitu sekitar $80 \%$, sedangkan perusahaan swasta dan pemerintah masing-masing 10\% (Darmawan et al., 2012). Produk karet yang dihasilkan diekspor sekitar $84 \%$ (2,6 juta ton) sedangkan sisanya $16 \%$ (0,49 juta ton) untuk kebutuhan dalam negeri. Produksi karet alam tersebut sebagian besar diolah menjadi karet remah (crumb rubber), ribbed smoke sheet (RSS), dan lateks pekat. Dari pengolahan karet RSS lateks pekat terdapat lump yang diolah menjadi brown crepe. Bahan baku brown crepe juga diperoleh dari 
lump kebun (Yulianti et al., 2005; Marimin et $a l$. , 2014). Di Jawa Tengah industri karet brown crepe ada lima pabrik.

Proses pengolahan industri karet brown crepe juga menghasilkan limbah cair, limbah padat dan gas buang serta kebisingan. Bahan baku berpengaruh terhadap kualitas dan kuantitas limbah yang dihasilkan. Kualitas dan kuantitas bahan baku semakin jelek/kotor maka air yang dibutuhkan untuk mencuci akan semakin banyak, dengan demikian air yang terbuang juga semakin banyak dan tentu saja debit air limbah juga semakin bertambah besar (Mohammadi et al., 2010; Darmawan et al., 2012). Limbah organik akan mudah membusuk, sehingga menimbulkan bau yang tidak sedap (Myra et al., 2015). Kuantitas lumpur, tatal dan pasir yang tinggi disebabkan karena bahan baku olahan yang kotor. Pengecilan ukuran bahan baku dilakukan untuk pembersihan kotoran dan juga untuk mempersingkat pengeringan supaya tidak terlalu lama (Hakim et al., 2016).

Kandungan komponen karet pada limbah cair karet brown crepe adalah protein, lipid, karotenoid dan garam anorganik. Lateks yang tidak terkoagulasi dan bahan kimia yang di tambahkan selama pengolahan terkoagulasi (Saravanan et al., 2013; Sharma et al., 2014). Produksi karet menghasilkan limbah cair \pm 400 $\mathrm{m}^{3}$ per hari. Limbah cair yang keluar dari pabrik dikumpulkan dalam kolam penampungan dan setelah 3 hari limbah cair tersebut baru dibuang ke sungai (Wardani et al., 2009). Inilah yang menyebabkan bau dan timbul gas amonia yang lebih banyak. Limbah cair pabrik karet brown crepe berwarna keruh dan berbau busuk karena adanya protein yang membusuk, sehingga menambah beban pencemar dari limbah cair tersebut dan mencemari lingkungan, baik pencemaran udara maupun air. Nilai COD dan BOD pada limbah cair karet brown crepe tinggi karena disebabkan oleh adanya bahan-bahan organik dari limbah cair karet sehingga perlu pengolahan (Hakim et al., 2016).

Pengolahan limbah cair brown crepe pada industri karet umumnya menggunakan rubber trap tanpa pengolahan kimia, sehingga limbah cair hanya lewat saja, karena over capacity sehingga tidak memenuhi baku mutu limbah cair yang sudah ditetapkan oleh masing-masing pemerintah daerah. Untuk itu perlu dicoba pengolahan dengan bahan kimia (flokulasikoagulasi) pada limbah cair brown crepe dan adsorpsi agar hasilnya memenuhi persyaratan yang berlaku. Koagulasi didefinisikan sebagai proses destabilisasi muatan koloid padatan tersuspensi termasuk bakteri dan virus dengan suatu koagulan yang dapat diendapkan. Flokulasi merupakan proses pembentukan flok, yang pada dasarnya merupakan pengelompokkan atau aglomerasi antara partikel dengan koagulan dengan pengadukan yang lambat (Risdianto, 2007; Suherman \& Sumawijaya, 2013). Terbentuknya flok-flok halus adalah proses pencampuran bahan kimia (koagulan) dengan air baku sehingga membentuk campuran yang homogen. Flok-flok kecil terdiri dari partikelpartikel koloid yang menggumpal dan selanjutnya membentuk flok yang lebih besar untuk bisa mengendap yang disebut proses pengendapan (Hakim et al., 2016).

Koagulan yang biasa digunakan untuk pengendapan pada proses pengolahan air limbah adalah tawas, sodium aluminat, poly aluminium chlorida (PAC), feri sulfat, feri klorida dan ferro sulfat (Mulyadi, 2007). Beberapa mekanisme koagulasi bisa berlangsung untuk pengolahan air limbah. Dalam koagulasi, apabila penambahan aluminium sulfat dan feri klorida jumlahnya mencukupi akan terjadi pengendapan $\mathrm{Al}(\mathrm{OH})_{3}$ dan $\mathrm{Fe}(\mathrm{OH})_{3}$. Partikel-partikel yang terdapat di dalam air terjaring di dalam endapan-endapan dan bersifat mudah melekat, sehingga agregasi terhadap flok dapat terjadi. Bisa juga jika aluminium sulfat atau feri klorida ditambahkan ke dalam air, maka akan terbentuk sejumlah spesies yang bermuatan positif $\left(\mathrm{Al}^{3+}\right.$ atau $\left.\mathrm{Fe}^{3+}\right)$. Spesies ini akan teradsorpsi dengan mudah terhadap partikel koloid yang bermuatan negatif sehingga terjadi netralisasi muatan. Mekanisme ini dikenal sebagai adsorpsi destabilisasi (Mohammadi et al., 2010).

Tawas adalah koagulan yang biasa digunakan untuk pengendapan, karena mudah didapat di pasaran dan harganya murah. Disamping itu juga mudah larut di dalam air membentuk ion $\mathrm{Al}^{3+}$ dan sulfat $\left(\mathrm{SO}_{4}^{-}\right)$. Tawas mempunyai daya guna yang optimum dalam proses koagulasi dengan $\mathrm{pH}$ berkisar antara 5 sampai dengan 8 (Suherman \& Sumawijaya, 2013). Ion $\mathrm{Al}^{3+}$ di dalam air terhidrolisa menjadi $\mathrm{Al}(\mathrm{OH})_{3}$ dalam bentuk koloid dalam suasana basa. Tawas yang berlebihan selain terbentuk $\mathrm{Al}(\mathrm{OH})_{3}$ yang mengendap juga terbentuk senyawa kompleks $\mathrm{Al}_{6}(\mathrm{OH})_{15^{3+}}, \mathrm{Al}_{7}(\mathrm{OH})_{17^{4+}}$, $\mathrm{Al}_{8}(\mathrm{OH})_{20}{ }^{4+}$ yang larut dalam air. Penyerapan bagian permukaan tersuspensi yang bermuatan negatif dimiliki oleh senyawa kompleks 
alumunium ini (Puspitasari \& Hadi, 2014). Dengan demikian dalam suasana basa fungsi koagulan akan lebih efektif.

Pengolahan yang cukup efektif dan ekonomis ketika kandungan padatan terlarut dalam air limbah terlalu besar, maka yang dapat menjadi solusi adalah pengolahan secara kimia. Koagulan ditambahkan untuk mendestabilisasi partikel koloid sehingga membentuk agregat yang lebih berat. Ini berarti akan mempersingkat waktu pengendapan dan meningkatkan efisiensi kolam sedimentasi. Apabila koagulan yang digunakan tidak terlalu banyak juga dapat mempercepat proses pengendapan partikel tersuspensi dalam air limbah.

Limbah cair karet brown crepe memiliki kandungan BOD, COD dan TSS yang cukup tinggi sehingga perlu pengolahan secara kimia karena aktifitas bakteri di dalam air limbah cair brown crepe menambah nilai BOD, COD, TSS dan amonia. Perubahan ini disebabkan oleh bakteri yang mampu menguraikan bahan organik limbah menjadi gas $\mathrm{CO}_{2}$, air dan amonia (Mohammadi et al., 2010; Anwar et al., 2013). Mikrobia yang merombak bahan organik limbah cair akan menyesuaaikan diri (optimum) pada kisaran $\mathrm{pH}$ 6,5-8,3. Perubahan nilai BOD, COD, TSS dan amonia disebabkan oleh perombakan bakteri pada limbah cair tersebut (Wardhani et al., 2009; Puspitasari et al., 2005).

Sand filter (saringan pasir) adalah salah satu cara pengolahan limbah cair dengan melewati pasir sebagai filter. Bahan pencemar akan bertumbukan dan menjerap ke permukaan partikel-partikel pasir. Bakteri dan zat padat yang terapung mulai meningkat dalam kepadatan yang tinggi di lapisan pasir paling atas menuju ke adsorben arang tempurung kelapa (Puadji et al., 2014). Salah satu unit operasi penyaringan adalah pengolahan air minum, yaitu dengan memindahkan padatan tersuspensi dari buangan pengolahan secara biologi atau secara koagulasi. Yang terpenting dalam proses penyaringan adalah media saringan. Kekeruhan dari buangan, tinggi lapisan penyaringan, pencucian kembali dan ketinggian resistensi kimia adalah faktorfaktor yang berpengaruh pada penyaringan (Utami, 2013; Riadi et al., 2011).

Dewasa ini, kinerja suatu perusahaan tidak lagi dapat dievaluasi berdasarkan parameter ekonomi saja, karena saat ini kinerja perusahaan juga harus terintegrasi dengan kinerja lingkungan (Marimin et al., 2013), sehingga penanganan limbah menjadi hal yang penting, karena menyangkut orang-orang disekitarnya. Tujuan dari penelitian ini adalah untuk mengetahui seberapa jauh penurunan beban pencemar dari pengolahan limbah cair brown crepe ini dengan 3 cara pengolahan yaitu penggunaan bak pencampur, pengendap dan adsorpsi, penggunaan bak saringan pasir (sand filter) dengan arang tempurung kelapa sebagai adsorben, dan kombinasi antara keduanya.

\section{BAHAN DAN METODE Bahan Penelitian}

Bahan yang digunakan dalam penelitian ini adalah limbah cair brown crepe yang diambil dari PTPN IX Batujamus Karanganyar. Bahanbahan lain untuk pengolahan limbah yaitu alum, polyelectrolyte (PE), $\mathrm{NaOH}$, arang tempurung kelapa, pasir, ijuk, krakal, dan krikil.

\section{Peralatan Penelitian}

Peralatan yang digunakan dalam penelitian ini adalah peralatan gelas seperti gelas ukur, beaker glass, ember, pengaduk, rangkaian alat pengolah limbah cair untuk percobaan dan kelengkapannya seperti bak penampung limbah cair, bak pencampur limbah dengan bahan kimia dan bak pengendapan, bak adsorpsi dan bak saringan pasir.

\section{Metode Penelitian}

Penelitian untuk mengolah limbah cair brown crepe ini dilakukan dengan 3 percobaan yaitu, percobaan 1 menggunakan model rangkaian bak penampung dengan volume 201 , bak pencampur dengan volume 5 liter yang dilengkapi dengan bahan pengendap (alum 400 $\mathrm{g} / \mathrm{l}$ ), bahan flokulan (PE 0,01\%) dan bahan untuk mengatur $\mathrm{pH}$ (larutan $\mathrm{NaOH} 5 \%$ ), bak pengendap dan bak adsorpsi menggunakan arang tempurung kelapa, seperti ditunjukkan pada Gambar 1.

Percobaan 2 menggunakan rangkaian sand filter berupa bak penampung, bak adsorpsi dengan menggunakan arang tempurung kelapa, dengan debit yang variasinya $0,5 \mathrm{ml} /$ detik, 2 $\mathrm{ml} /$ detik dan 3,5 $\mathrm{ml} /$ detik, seperti ditunjukkan pada Gambar 2. Rangkaian IPAL ini merupakan alternatif pengolahan limbah yang tidak perlu menggunakan listrik, yaitu apabila IPAL terletak di tengah kebun karet yang kesulitan mendapatkan sumber listrik.

Percobaan 3 menggunakan kombinasi antara percobaan 1 dan percobaan 2 yaitu menggunakan pengolahan kimia (rangkaian bak 


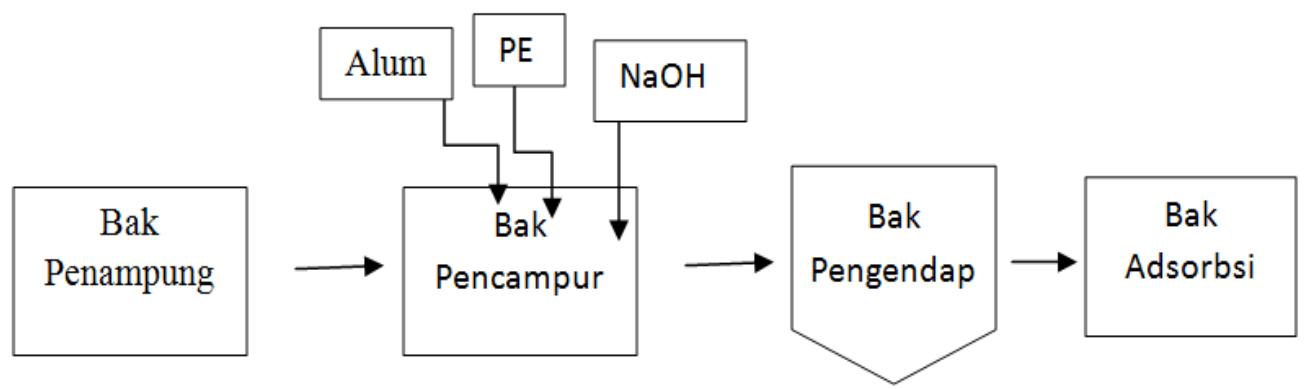

Gambar 1. Diagram alir percobaan 1.

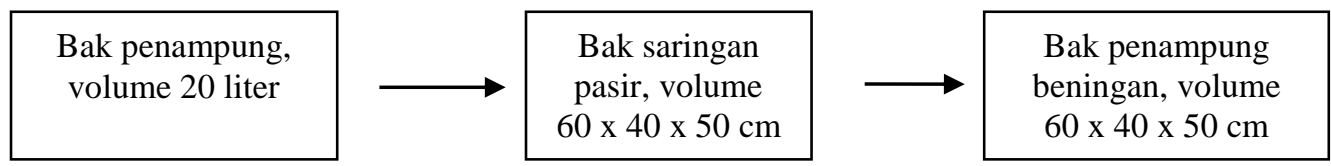

Gambar 2. Diagram alir percobaan 2.

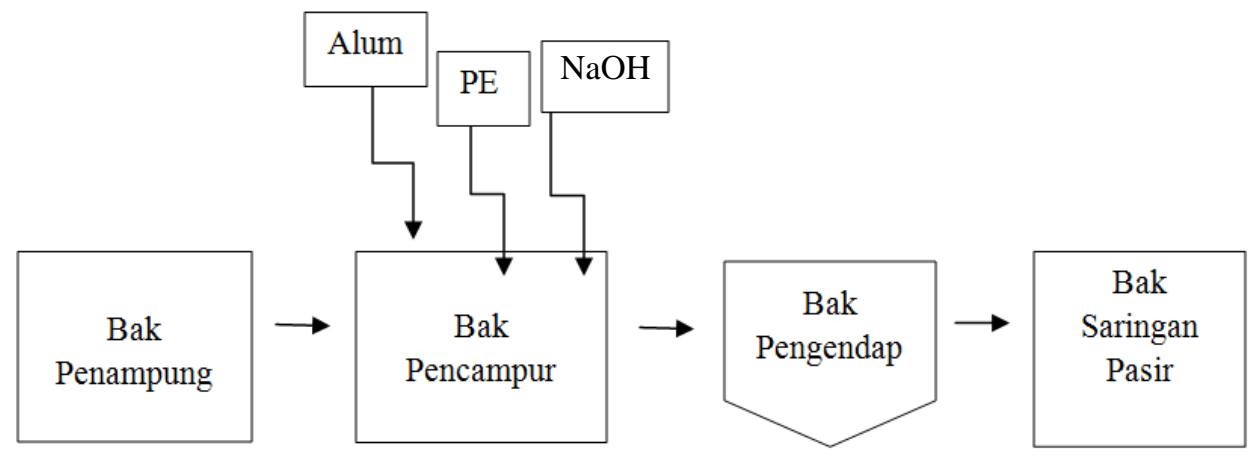

Gambar 3. Diagram alir percobaan 3.

penampung, bak pencampur dan bak pengendap yang dilanjutkan dengan bak saringan pasir dengan adsorben arang tempurung kelapa), seperti ditunjukkan pada Gambar 3. Kondisi operasi sama dengan percobaan 1 dan 2 tentang jumlah bahan, debit dan lainnya.

Limbah cair brown crepe diambil dari salah satu industri karet brown crepe dibawa ke Laboratorium Produksi Bersih dan Lingkungan (PBL), selanjutnya dilakukan percobaan pertama dengan rangkaian peralatan pengolahan limbah cair yaitu rangkaian pengolahan primer yang terdiri dari bak penampung, bak pencampur yang lengkap dengan tabung alum, $\mathrm{PE}, \mathrm{NaOH}$, bak pengendap dan bak adsorpsi. Percobaan kedua dengan rangkaian bak penampung diteruskan ke bak saringan pasir. Percobaan ketiga dengan menggunakan rangkaian bak penampung, bak pencampur yang dilengkapi dengan bak alum, $\mathrm{PE}$ dan $\mathrm{NaOH}$, bak penendap yang selanjutnya dialirkan ke bak saringan pasir.
Dari ketiga percobaan tersebut limbah cair dari bak penampung (inlet) dan bak terakhir (outlet) diambil dan diuji COD, BOD, TSS dan amonia sehingga diketahui hasil uji dari influent dan efluent serta seberapa jauh penurunan parameter limbah tersebut dengan 3 metode pengolahan yang telah dilakukan.

\section{HASIL DAN PEMBAHASAN}

Pengolahan Limbah Cair dengan Koagulasi dan Flokulasi Dilanjutkan Adsorpsi

Pada percobaan 1, bak pencampur sudah dilengkapi dengan tempat alum dengan konsentrasi alum $4 \%$ dengan penggunaan $4 \mathrm{ml} / \mathrm{l}$, PE $0,2 \%$ dengan penggunaan $2 \mathrm{ml} / 1$ dan pemberian $\mathrm{NaOH}$ dengan konsentrasi $1 \%$ sampai pH 8-9. Dari percobaan 1 didapatkan hasil uji seperti ditunjukkan pada Tabel 1 .

Dari Tabel 1 dapat dilihat bahwa parameter COD (494,2 mg/l) dan BOD (327,5 mg/l) belum memenuhi baku mutu standar yaitu COD (300 
$\mathrm{mg} / \mathrm{l})$ dan BOD (150 mg/l). Sehingga masih dibutuhkan model pengolahan yang lebih sesuai. Untuk parameter TSS dan amonia sudah memenuhi standar yang ditetapkan (Gubernur Provinsi Jawa Tengah, 2012). Penggunaan standar ini disesuaikan dengan lokasi industri brown crepe yang berada di Jawa Tengah.

Gambar 4. menunjukkan grafik presentase penurunan kadar limbah yang diolah menggunakan percobaan 1. Dari grafik penurunan kadar limbah pada percobaan 1 dapat dilihat bahwa penurunan COD pada bak pengendapan $64 \%$, dan pada bak adsorpsi $76 \%$, sedangkan penurunan kadar BOD pada bak pengendapan 55\%, dan pada bak adsorpsi $74 \%$. Penurunan kadar limbah terbaik pada percobaan 1 adalah TSS pada bak pengendap 92\% dan bak adsorpsi $95 \%$. Penurunan kadar amonia pada bak pengendap 90\% dan pada bak adsorpsi $91 \%$. Hal ini menunjukkan bahwa percobaan 1 ini paling cocok untuk menurukan TSS dan amonia, karena penurunan kadar polutannya lebih dari $90 \%$. Hasil uji memenuhi baku mutu yang ditetapkan oleh Gubernur Provinsi Jawa Tengah (2012).

Senyawa aluminat merupakan gugus utama proses koagulasi yang optimum pada $\mathrm{pH}$ netral. Air akan kelihatan seperti air baku apabila $\mathrm{pH}$ nya tinggi, dengan kata lain adalah kekurangan dosis. Hal ini dikarenakan gugus aluminat tidak terbentuk secara sempurna, namun bila kelebihan dosis atau pH-nya rendah maka air kelihatan keputih-putihan karena kebanyakan konsentrasi alum yang kecenderungannya mempunyai warna putih. Berikut adalah reaksi alum.

$$
\mathrm{Al}_{2} \mathrm{SO}_{4}+6 \mathrm{H}_{2} \mathrm{O} \rightarrow 2 \mathrm{Al}(\mathrm{OH})_{3}+6 \mathrm{H}^{+}+\mathrm{SO}_{4}{ }^{2-}
$$

Dari reaksi ini dapat diketahui bahwa ada pembebasan ion $\mathrm{H}^{+}$yang mempunyai kadar yang tinggi dan ditambah dengan adanya ion aluminium. Ion aluminium bersifat amfoter sehingga (bisa bersifat asam tapi juga bisa bersifat basa).

Aluminium akan tergantung dari sifat yang mempengaruhi lingkungannya. Dikarenakan suasana dalam larutan ini asam maka aluminium bersifat asam dan larutan $\mathrm{pH}$ menjadi turun. Dalam realita nya ion $\mathrm{Al}^{3+}$ dalam larutan koagulan terhidrasi dan mempunyai ketergantungan dengan $\mathrm{pH}$ hidrolisa. Senyawa yang terjadi berinteraksi dengan kotoran seperti koloid dan mempunyai muatan positif.

\section{Pengolahan Limbah Cair Brown Crepe dengan Saringan Pasir}

Percobaan 2 merupakan pengolahan limbah cair hanya dengan saringan pasir yang menggunakan adsorben arang tempurung kelapa dan variasi debit. Hasil uji dari percobaan 2 dapat ditunjukkan pada Tabel 2. Dari Tabel 2 terlihat nilai kadar limbah yang sangat tinggi, dikarenakan sebelum percobaan dilakukan, limbah telah disimpan beberapa waktu.

Nilai yang diperhitungkan adalah persentase penurunan kadar limbah setelah melalui proses percobaan pengolahan. Walaupun persentase penurunan parameter COD tinggi, namun nilai

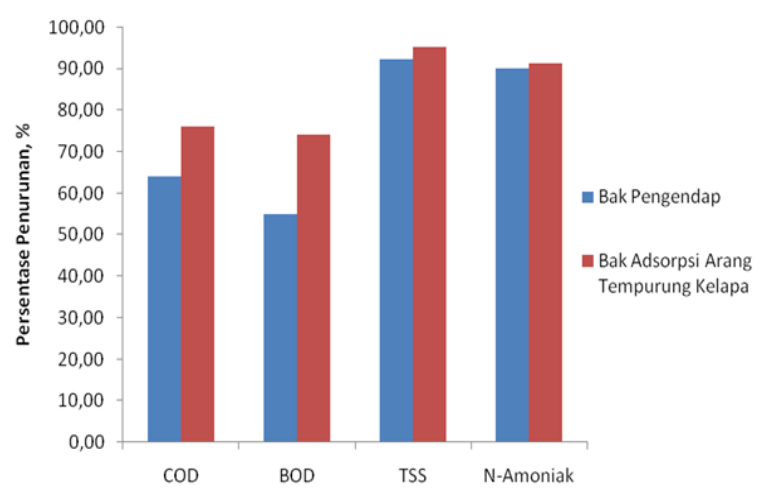

Gambar 4. Grafik penurunan kadar limbah percobaan 1.

Tabel 1. Hasil uji limbah cair brown crepe pada percobaan 1.

\begin{tabular}{lrrrr}
\hline \multirow{2}{*}{ Parameter } & \multicolumn{3}{c}{ Hasil uji (mg/l) } & \multirow{2}{*}{ Standar* } \\
\cline { 2 - 4 } & \multicolumn{1}{c}{ A } & \multicolumn{1}{c}{ B } & \multicolumn{1}{c}{ C } \\
\hline COD & 2051,7 & 737,60 & 494,20 & 300 \\
BOD & 1256,5 & 567,50 & 327,50 & 150 \\
TSS & 710,0 & 55,00 & 35,00 & 150 \\
N-Amonia & 30,1 & 3,06 & 2,64 & 10 \\
\hline
\end{tabular}

Keterangan:

$\mathrm{A}=$ Limbah asli dari bak penampung

$\mathrm{B}=$ Limbah cair yang keluar dari bak pengendap.

$\mathrm{C}=$ Limbah cair yang keluar dari bak adsorpsi arang tempurung kelapa

* Gubernur Provinsi Jawa Tengah (2012) 
Tabel 2. Hasil uji percobaan 2 dengan adsorben arang tempurung kelapa.

\begin{tabular}{|c|c|c|c|c|c|}
\hline \multirow[t]{2}{*}{ Parameter } & \multicolumn{4}{|c|}{ Hasil uji (mg/l) } & \multirow[t]{2}{*}{ Standar* } \\
\hline & I & IA & IB & IC & \\
\hline COD & 6820,8 & 836,00 & 668,8 & 601 & 300 \\
\hline BOD & 1187,0 & 81,11 & 61,8 & 55,8 & 150 \\
\hline TSS & 25,5 & 6,00 & 6,0 & 4,0 & 150 \\
\hline N-Amonia & 53,4 & 24,90 & 19,7 & 20,6 & 10 \\
\hline $\begin{array}{l}\text { Keterangan: } \\
\text { I = limbah cair } b r \\
\text { IA = limbah cair } b r \\
\text { IB = limbah cair } b r \\
\text { IC = limbah cair } b r\end{array}$ & $\begin{array}{l}\text { i drum penan } \\
\text { sand filter } \mathrm{m} \\
\text { sand filter } \mathrm{m} \\
\text { sand filter } \mathrm{m}\end{array}$ & $\begin{array}{l}\text { kan adsorbe } \\
\text { kan adsorbe } \\
\text { kan adsorbe }\end{array}$ & $\begin{array}{l}\text { empurung k } \\
\text { empurung k } \\
\text { empurung k }\end{array}$ & $\begin{array}{l}\text { ngan debit } \\
\text { engan debi } \\
\text { ngan debit }\end{array}$ & $\begin{array}{l}\text { /det } \\
\text { letik } \\
\text { detetik }\end{array}$ \\
\hline
\end{tabular}

Tabel 3. Hasil uji percobaan 3 adalah kombinasi antara percobaan 1 dan percobaan 2 .

\begin{tabular}{lrrrr}
\hline \multirow{2}{*}{ Parameter } & \multicolumn{3}{c}{ Hasil uji (mg/l) } & Standar* (mg/l) \\
\cline { 2 - 3 } & \multicolumn{1}{c}{ Inlet } & Bak pengendap & Outlet & \\
\hline COD & 2155,2 & 898,0 & 754,3 & 300 \\
BOD & 217,0 & 90,6 & 74,5 & 150 \\
TSS & 315,0 & 48,5 & 35,5 & 150 \\
N-Amonia & 34,6 & 10,6 & 6,4 & 10 \\
\hline
\end{tabular}

Keterangan:

*Gubernur Provinsi Jawa Tengah (2012)

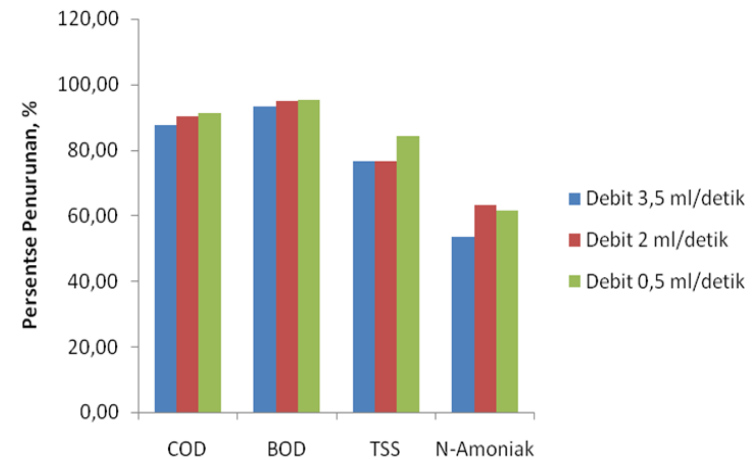

Gambar 5. Grafik persentase penurunan kadar limbah percobaan 2 .

COD belum memenuhi persyaratan yang diterbitkan oleh Gubernur Provinsi Jawa Tengah (2012) yaitu pada angka $300 \mathrm{mg} / \mathrm{l}$. Persentase penurunan kadar limbah cair brown crepe pada percobaan 2 dapat ditunjukkan pada Gambar 5.

Dari perlakuan percobaan 2 terlihat bahwa penggunaan sand filter dengan adsorben arang tempurung kelapa dapat menurunkan kadar COD dan BOD hingga 90\%, kadar TSS hingga $80 \%$ dan kadar $\mathrm{N}$-amoniak hingga $60 \%$. Untuk debit aliran tidak berpengaruh signifikan terhadap presentasi penurunan kadar limbah.

\section{Pengolahan Limbah Cair Brown Crepe dengan Koagulasi-flokulasi dan Saringan Pasir}

Percobaan 3 adalah kombinasi dari percobaan 1 dan 2 yang terdiri dari bak penampung, bak pencampur, bak pengendap dan bak saringan pasir dengan adsorben arang tempurung kelapa. Hasil uji dari percobaan 3 ditunjukkan pada Tabel 3.

Dari Tabel 3. terlihat bahwa outlet percobaan 3 menghasilkan limbah yang belum memenuhi baku mutu yang ditetapkan oleh Gubernur Provinsi Jawa Tengah (2012) pada parameter COD. Untuk parameter BOD, TSS, dan N-Amonia sudah memenuhi baku mutu. Persentase penurunan kadar limbah yang diproses dengan percobaan 3 ditunjukkan pada Gambar 6. Disini terlihat bahwa penurunan beban pencemar pada parameter COD dan BOD adalah sama, yaitu pada bak pengendap sebesar $58 \%$ dan pada outlet sebesar $65 \%$. Sedangkan pada bak pengendap parameter TSS sebesar $84,60 \%$ dan pada Outlet sebesar $88,73 \%$. Penurunan amonia bak pengendap sebesar $69 \%$ dan pada outlet sebesar $81,50 \%$. 


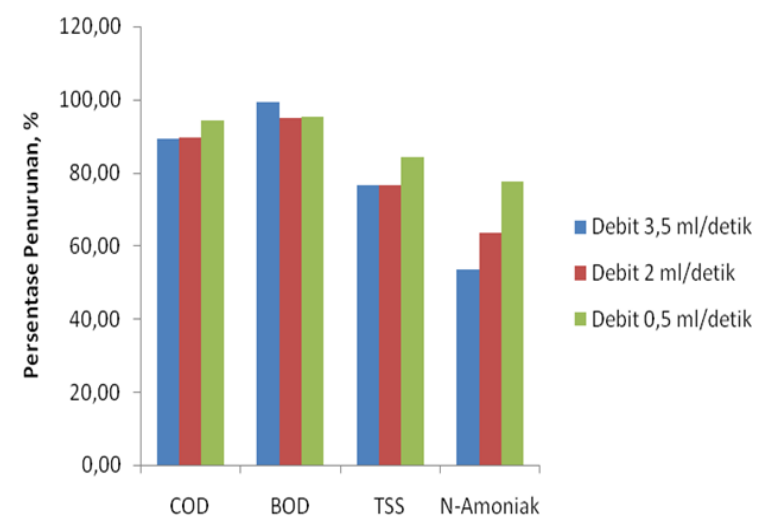

Gambar 6. Grafik persentase penurunan kadar limbah percobaan 3 .

\section{KESIMPULAN}

Dari ketiga percobaan semuanya dapat untuk menurunkan beban pencemar COD 63\%$91 \%$, BOD $74 \%-95 \%$, TSS $84 \%-95 \%$, NAmonia 61\%-91\%. Namun penurunan COD dan BOD terbaik adalah percobaan 2 yaitu sekitar 91\%-95\%, Penurunan terbaik TSS dan NAmonia pada percobaan 1 yaitu sekitar 91\%95\%. Dengan kata lain ketiga percobaan dapat menyelesaikan masalah lingkungan, namun yang terbaik adalah percobaan 3 (kombinasi percobaan 1 dan percobaan 2).

\section{UCAPAN TERIMA KASIH}

Penulis mengucapkan terima kasih kepada Kepala Balai Besar Kulit, Karet dan Plastik yang telah memberi kepercayaan dan dana untuk melakukan penelitian, serta kepada semua anggota tim pokja 1866.001.011 dan semua personil yang telah membantu dalam pelaksanaan kegiatan penelitian ini.

\section{DAFTAR PUSTAKA}

Anwar, N. Z. R., Hassan, M. A. A., Mahmood, I., \& Khamis, A. K. (2013). Treatment of rubber processing wastewater by effective microorganisms using anaerobic sequencing batch reactor. Journal of Agrobiotechnology, 4, $1-15$.

Darmawan, M. A., Wiguna, B., Marimin, \& Machfud. (2012). Peningkatan produktivitas proses produksi karet alam dengan pendekatan green productivity: Studi kasus di PT. X. Jurnal Teknologi Industri Pertanian, 22(2), 98-105.

Gubernur Provinsi Jawa Tengah. (2012). Peraturan Daerah Provinsi Jawa Tengah Nomor 5 tahun 2012 tentang Perubahan atas Peraturan Daerah Provinsi Jawa Tengah Nomor 10 Tahun 2004 tentang Baku Mutu Air Limbah. Semarang, Indonesia.
Hakim, W. N., Pinem, J. A., \& Saputra, E. (2016). Pengolahan limbah cair industri karet dengan kombinasi proses pretreatment dan membran ultrafiltrasi. Jurnal Online Mahasiswa Fakultas Teknik Universitas Riau, 3(1), 1-9.

Marimin, Darmawan, M. A., Machfud, \& Putra, M. P. I. F. (2013). Peningkatan produkstivitas proses budidaya karet alam dengan pendekatan green productivity: Studi kasus di PT. XYZ. Agritech, 33(4), 433-441. https://doi.org/10.22146/agritech.9539

Marimin, Darmawan, M. A., Martini, S., \& Rahmanto, A. D. (2014). Green productivity improvement model for pre-processed rubber (bokar): Case study at rubber small-holders plantation. In 2nd International Conference on Technology, Informatics, Management, Engineering, \& Environment, 135-140. https://doi.org/10.1109/TIME-E.2014.7011606

Mohammadi, M., Man, H. C., Hassan, M. A., \& Yee, P. L. (2010). Treatment of wastewater from rubber industry in Malaysia. African Journal of Biotechnology, 9(38), 6233-6243. https://doi.org/10.5897/AJB09.031

Mulyadi. (2007). Chemical process control in water treatment. Reguler Training, Serpong, Aula IPA Cisadane.

Myra, T., David, H., Judith, T., Marina, Y., Ricky, B. J., \& Reynaldo, E. (2015). Biological treatment of meat processing wastewater using anaerobic sequencing batch reactor (ASBR). International Research Journal of Biological Sciences, 4(3), 66-75.

Puadji, R., Saraswati, D., \& Abudi, R. (2014). Analisis perbedaan kadar BOD dan COD air limbah yang menggunakan biosand filter dengan yang tidak menggunakan pada industri rumah tangga (IRT) laundry di Kec. Kota Tengah Kota Gorontalo. Karya Ilmiah Mahasiswa Fakultas Ilmu Kesehatan dan Keolahragaan Universitas Gorontalo, 2(3).

Puspitasari, D. A., Pangastuti, A., \& Winarno, K. (2005). Isolasi bakteri pendegradasi limbah industri karet dan uji kemampuannya dalam perbaikan kualitas limbah industri karet. Bioteknologi, 2(2), 49-53. http://doi.org/10.13057/biotek/c020203

Puspitasari, M., \& Hadi, W. (2014). Efektifitas $\mathrm{Al}_{2}\left(\mathrm{SO}_{4}\right)_{3}$ dan $\mathrm{FeCl}_{3}$ dalam pengolahan air minum menggunakan gravel bed flocculator ditinjau dari parameter kekeruhan dan total coli. Jurnal Teknik ITS, 3(2), 162-166.

Riadi, F., Machfud, Bantacut, T., \& Sailah, I. (2011). Model pengembangan agroindustri karet alam terintegrasi. Jurnal Teknologi Industri Pertanian, 21(3), 146-153.

Risdianto, D. (2007). Optimisasi proses koagulasi flokulasi untuk pengolahan air limbah industri 
jamu (studi kasus PT. Sido Muncul) (Tesis). Universitas Diponegoro, Indonesia.

Saravanan, P., Kumar, S. S., \& Ajithan, C. (2013). Eco-friendly practice of utilization of food wastes. International Journal of Pharmaceutical Sciences Innovation, 2(1), 14-17.

Sharma, A., Sharma, R., Arora, A., Shah, R., Singh, A., Pranaw, K., \& Nain, L. (2014). Insights into rapid composting of paddy straw augmented with efficient microorganism consortium. International Journal of Recycling of Organic Waste in Agriculture, 3, 54. http://doi.org/10.1007/s40093-014-0054-2

Suherman, D., \& Sumawijaya, N. (2013). Menghilangkan warna dan zat organik air gambut dengan metode koagulasi-flokulasi suasana basa. Riset Geologi dan Pertambangan, 23(2), 125-137.
Utami, A. R. (2013). Pengolahan limbah cair laundry dengan menggunakan biosand filter dan activated carbon. Jurnal Teknik Sipil UNTAN, 13(1), 59-72.

Wardhani, R. S., Iswanto, B., \& Winarni. (2009). Pengaruh $\mathrm{pH}$ pada proses koagulasi dengan koagulan alumunium sulfat dan feri klorida. Jurnal Teknologi Lingkungan Universitas Trisakti, 5(2), 40-45.

Yulianti, D., Winarno, K., \& Mudyantini, W. (2005). Pemanfaatan limbah cair pabrik karet PTPN IX Kebun Batu Jamus Karanganyar hasil fitoremediasi dengan Azolla microphylla Kaulf untuk pertumbuhan tanaman padi (Oryza sativa Linn.). BioSMART, 7(20), 125-130. 